\title{
A Data-Driven Approach to Increasing Student Motivation in the Reading Classroom
}

\author{
Darrell Wilkinson \\ Soka University, Tokyo, Japan
}

\begin{abstract}
Reading is widely accepted as one of the most important second-language skills as it offers language learners the opportunity to acquire a variety of lexical items, grammatical structures, and additional schematic knowledge. In an EFL or ESL context, two approaches to teaching reading, intensive and extensive reading, have generally been adopted. When employing intensive reading in a group context, the teacher faces many challenges, e.g., finding material interesting to all students and dealing with mixed levels, individual learner differences, and low motivation. After describing an action research project designed to indicate motivation for reading among two groups of Japanese college students and analyzing the results of that project, the author outlines a nontraditional, more holistic, and student-centered approach to intensive and extensive reading. This approach aims to overcome students' low intrinsic motivation by adopting a more differentiated learning approach and applying some extensive reading principles to intensive reading.
\end{abstract}

Although the ability to read effectively in a foreign language is widely viewed as one of the most important skills that a foreign language learner can possess, the teaching of reading poses a range of challenges, both pedagogical and logistical. From a pedagogical perspective, issues such as what type of reading should be carried out, what skills are necessary, how to teach these skills, and how to strike a balance between explicit instruction and time on task are still being discussed and researched (see Carrell, Devine, \& Eskey, 1988; Hunt \& Beglar, 2005; Macalister, 2008; Nation, 2009; Sehlaoui, 2001). For designers of the intensive reading component of a language course, the choice of materials (level, genre, style, and amount) and the grouping of students into levels are two of the biggest issues. Students' second language levels vary considerably in many foreign language courses, causing many problems for students (Childs, 2002; DelliCarpini, 2006; Prodromou, 1989; Sehlaoui, 2001; Šimanová, 2010).

\section{Literature Review}

\section{The Importance of Reading in a Foreign Language}

Many educators such as Carrell, Devine, \& Eskey (1988) believe reading is the most important foreign language skill. Reading is vital, as it provides the opportunity for the acquisition and review of a variety of lexical items and grammatical structures. Krashen and Terrell (1983)

Language Education in Asia, 2012, 3(2), 252-262. http://dx.doi.org/10.5746/LEiA/12/V3/I2/A13/Wilkinson 
stated that "reading may ... contribute significantly to competence in a second language. There is good reason, in fact, to hypothesize that reading makes a contribution to overall competence, to all four skills" (p. 131). Additionally, in an EAP setting, reading is essential for the acquisition of new content knowledge, due to the vast amount of literature worldwide that is only available in English (Macalister, 2008).

\section{Reading in a Foreign Language: Two Main Approaches}

Although an increasing number of reading courses are now including speed reading, for many years, a large number of foreign language teachers have focused on extensive and intensive reading. Both approaches, widely researched and written about, offer distinct benefits in the development of foreign language reading skills.

Extensive reading. With extensive reading, learners read a large quantity of material within their linguistic level. As Day and Bamford elaborated, "for extensive reading to be possible and for it to have the desired results, texts must be well within the learners' reading competence in the foreign language" (2002, p. 139). Another important principle of extensive reading noted by many authors, including Bell (1998), Nation (1997), Renandya and Jacobs (2002), and Waring (1997), is that large amounts of level-appropriate material must be read regularly. A third key principle is that learners should have a wide variety of materials to choose from and have complete autonomy in the choice of readings. Autonomy and choice are often credited for increasing motivation levels and developing autonomous learners. Grabe (1991) referred to these and other benefits: "Longer concentrated periods of silent reading build vocabulary and structural awareness, develop automaticity, enhance background knowledge, improve comprehension skills, and promote confidence and motivation" (p. 396).

Intensive reading. Intensive reading material includes many vocabulary items and possibly grammatical forms that are difficult or new to the student. The intent is for students to explicitly study new words and employ reading skills (e.g., skimming, scanning, and guessing meaning from context). Bruton (2002) described intensive reading as "having comprehension and language-focused tasks completed communally by the whole class" (para 2). Brown (2007) similarly stated that intensive reading is usually "a classroom-oriented activity in which students focus on the linguistic or semantic details ... grammatical forms, discourse markers, and other surface structure details for the purpose of understanding" (p. 373). Intensive reading is essential when learning a foreign language, but presents many challenges, especially in a group context.

Summarizing the literature, extensive reading offers benefits and advantages not attributed to intensive reading. Overall, extensive reading is seen to be more enjoyable and motivating, and more easily applied to groups of mixed-ability learners. However, it has its limitations; therefore, intensive reading is also necessary to develop holistic, well-balanced, and comprehensive reading skills. Because of the importance of both approaches, the level of student motivation for extensive and intensive reading is the research focus of this article and increasing that motivation is the focus of the discussion of the results of the study.

\section{Identification of a Problem}

\section{Student Perceptions of Reading Courses}

After being responsible for two reading courses for one academic year at one college and one university and from talking to other reading teachers at each institution, it seemed that students were lacking in intrinsic motivation, which Deci and Ryan defined as "motivation to engage in 
an activity because that activity is enjoyable to do" $(1985$, p. 39$)$. Although many teachers felt that students had clear reasons and goals for studying and extrinsic motivation (e.g., to achieve higher standardized test scores, improve overall competency in English to study abroad or to gain employment), many students did not seem to enjoy reading classes. Students who were very enthusiastic in other classes, such as oral communication and academic writing, were seemingly uninterested and unenthusiastic in reading classes.

The hypothesis was that the reading materials were neither interesting nor suitably leveled for many of the students. Finding material of interest to all learners in a given class is very problematic for EFL / ESL teachers, as each student has his or her own interests and purpose for language study. In addition, for reading to be enjoyable and useful, the material must be at a comprehensible level. Laufer (1989) and Nation (2001) both stated that learners need to understand at least 95 percent of the words in a text if they are to gain reasonable comprehension. In many contexts, students are streamed, or split into classes based on assessment of their ability (Harlen \& Malcolm, 1997), and then one textbook is chosen for all students at that particular level. This is often an issue because streamed classes often still contain students at quite different language abilities or levels (Childs, 2002; DelliCarpini, 2006; Prodromou, 1989; Sehlaoui, 2001; Šimanová, 2010). Therefore, when adopting the "onebook-fits-all approach" (Wilkinson, 2012), it is very unlikely that the chosen textbook will be interesting or of a suitable level for all the students in the class.

\section{Participants}

Basic action research was carried out with two groups of students to discover their perceptions of their previous reading courses by giving a simple questionnaire. The first group consisted of 16 students placed in a pre-intermediate reading class. The second group comprised 17 students in an intermediate reading class. Both groups had taken two semesters of reading courses in the previous year, but not the same classes or teachers.

The students' TOEIC scores, the sole determinant in streaming students, showed that individual language abilities differed significantly. The score ranges, decided by the administration, were $305-500$ for the pre-intermediate group and 505 - 700 for the intermediate group. Each group contained students at either end of the range.

\section{Data Collection}

Assessing intrinsic and extrinsic motivation levels. The questionnaire used Likert scales for students to rate the class in terms of 1 ) enjoyability (intrinsic motivation) and 2) suitability to their study goals (extrinsic motivation). Students were also asked to provide open responses concerning their reasons for their ratings; however, not all students supplied responses. A summary of the results is given in Table 1. 
Table 1

Questionnaire Results on the Enjoyability and Suitability of Previous Reading Course

\begin{tabular}{|c|c|c|}
\hline Question Focus & Results & Main Reasons Given \\
\hline $\begin{array}{l}\text { Level of } \\
\text { enjoyment } \\
\text { (intrinsic } \\
\text { motivation) }\end{array}$ & $\begin{array}{c}\text { 85\%: not very enjoyable or } \\
\text { not at all enjoyable }\end{array}$ & $\begin{array}{l}53 \% \text { : Boring material } \\
45 \% \text { : Class was too difficult } \\
33 \% \text { : Not enough reading carried out } \\
18 \% \text { : Did not see the purpose of the class }\end{array}$ \\
\hline $\begin{array}{l}\text { Suitability to } \\
\text { study purposes } \\
\text { or goals } \\
\text { (extrinsic } \\
\text { motivation) }\end{array}$ & $\begin{array}{c}79 \% \text { : not very useful or } \\
\text { not at all useful }\end{array}$ & $\begin{array}{l}\text { 24\%: Not enough business- / TOEIC- } \\
\text { based texts } \\
\text { 21\%: Not enough academic - / TOEFL- } \\
\text { based texts } \\
\begin{array}{l}\text { 18\%: Not useful for life / Goal is speaking } \\
\text { ability }\end{array}\end{array}$ \\
\hline
\end{tabular}

Note. $n=33$

The above results proved the hypothesis that the majority of students did not enjoy their previous reading courses and had very little intrinsic motivation concerning reading. In addition, as $79 \%$ of the students responded that the course did not match their goals or purposes for studying, a problem concerning extrinsic motivation was highlighted.

Assessing student perceptions of reading course difficulty level. Students were also asked to rate the level of difficulty of their previous reading courses. Only 11 out of 33 students $(33 \%)$ responded that the level of the course was appropriate, while 14 students $(42 \%)$ perceived the course as too difficult or much too difficult and 8 students (24\%) indicated it was too easy or much too easy.

Assessing reading abilities. The above student responses and TOEIC score data highlighted a need to obtain a more accurate measure of student language level related to reading. Nation's $(1983,1990)$ Vocabulary Levels Test (VLT), an intensive reading test using TOEFL and TOEIC practice tests, and a speed reading test were given to the students before the course began. For the reading tests, each group received a different level of texts: Group 1 texts were from preintermediate textbooks and Group 2 texts from intermediate textbooks. Students were given the same amount of time to complete the tests. 
Table 2

Results of Pre-Course Language Level Tests

\begin{tabular}{|c|c|c|c|}
\hline \multirow{2}{*}{\multicolumn{2}{|c|}{ Test }} & \multicolumn{2}{|c|}{ Score Ranges } \\
\hline & & $\begin{array}{l}\text { Group 1: Pre-Intermediate } \\
\qquad n=16\end{array}$ & $\begin{array}{l}\text { Group 2: Intermediate } \\
\qquad n=17\end{array}$ \\
\hline \multirow[t]{2}{*}{$\begin{array}{l}\text { Vocabulary } \\
\text { Levels Test }\end{array}$} & $\begin{array}{l}1000 \text { word } \\
\text { level }\end{array}$ & $33 \%-83 \%$ & $43 \%-93 \%$ \\
\hline & $\begin{array}{l}2000 \text { word } \\
\text { level }\end{array}$ & $26 \%-77 \%$ & $33 \%-80 \%$ \\
\hline \multicolumn{2}{|c|}{ Intensive Reading } & $40 \%-90 \%$ & $30 \%-90 \%$ \\
\hline \multicolumn{2}{|c|}{ Speed Reading } & $30 \%-70 \%$ & $40 \%-70 \%$ \\
\hline
\end{tabular}

In summary, the questionnaire results showed that perceptions and feeling toward the previous reading course were very negative, and test data indicated that although placed into the same class, students' reading ability and vocabulary levels varied significantly.

It seemed clear that a solution which could increase both intrinsic motivation, through a more enjoyable and level-appropriate learning environment, and extrinsic motivation, by providing students with more goal-orientated texts, was very much needed. However, after a fairly extensive literature review, it appeared that a clear solution had not yet been identified. Much of the literature deals with adapting the materials, but this is very time consuming and difficult for any teacher with a reasonable teaching load. In addition, the suggestions did not deal with the problem of providing greater choice of genres, styles, or topics for a class including intensive reading. Therefore, a somewhat different approach to dealing with the problems was necessary.

\section{A Data-Based Solution: Design and Implementation of an Alternative Approach}

It was felt that a more student-centered approach that would result in learners actively developing reading skills and strategies, whilst reading plenty of appropriately-leveled material of interest to them was needed. The results of such conditions being met were hypothesized to be increased intrinsic and extrinsic motivation. It was important that this approach should not be too labor intensive and could be easily implemented within fairly typical administrative, financial, and logistical constraints.

\section{Underlying Principles of Approach Design}

Differentiated instruction. The basic premise for this new approach is in direct opposition to the statement "No one wants to use three different course books with one class: one for strong students, one for weak students, and one for midlevel students" (Bowler \& Parminter, 2002, p. 59). The approach adopts a form of differentiated instruction, which Tomlinson (2003) refers to as the matching of content and activities to each learner's level and interests.

Instead of choosing one textbook for each class, three levels each of the same intensive reading textbook and the same speed reading series were distributed to the students. The level a student received was based on the pre-course vocabulary test and reading test results. 
Extensive reading principles for intensive reading. After reviewing some of the principles and benefits of extensive reading set out by Bamford and Day (1997) and Day and Bamford (2002), it was decided that not only would students engage in regular extensive reading, but some of the features of extensive reading would be applied to the intensive reading component. This involved the creation of an intensive reading library containing academic, business, and general English reading materials at three levels. This was done using sample copies of textbooks from various publishers (with permission from the publishers), and photocopiable materials found online.

Table 3 shows four extensive reading principles from Day and Bamford (2002) that were applied, along with their main aims and the basic procedure involved.

Table 3

Extensive Reading Principles Applied to Intensive Reading

\begin{tabular}{|l|l|l|l|}
\hline & Extensive Reading Principle & \multicolumn{1}{|c|}{$\begin{array}{c}\text { Aim of } \\
\text { Application of Principle } \\
\text { to Intensive Reading }\end{array}$} & \multicolumn{1}{|c|}{ Procedure } \\
\hline 1 & $\begin{array}{l}\text { Reading material is of a } \\
\text { suitable level }\end{array}$ & $\begin{array}{l}\text { Dealing with mixed reading } \\
\text { abilities }\end{array}$ & $\begin{array}{l}\text { Provide multiple levels of } \\
\text { texts to the class }\end{array}$ \\
\hline 2 & $\begin{array}{l}\text { A variety of reading material } \\
\text { on a wide range of topics } \\
\text { must be available }\end{array}$ & $\begin{array}{l}\text { Increasing motivation by } \\
\text { providing material of } \\
\text { interest or relevance to } \\
\text { individual students }\end{array}$ & $\begin{array}{l}\text { Create an intensive reading } \\
\text { library containing various } \\
\text { text genres }\end{array}$ \\
\hline 3 & $\begin{array}{l}\text { Learners choose what they } \\
\text { want to read }\end{array}$ & $\begin{array}{l}\text { Increasing motivation and } \\
\text { autonomy }\end{array}$ & $\begin{array}{l}\text { Students choose what texts } \\
\text { to read from the library }\end{array}$ \\
\hline 4 & $\begin{array}{l}\text { Learners read as much as } \\
\text { possible }\end{array}$ & Providing more time on task & $\begin{array}{l}\text { The majority of the grade } \\
\text { for the course comes from } \\
\text { the amount read (part of the } \\
\text { grade comes from } \\
\text { comprehension scores) }\end{array}$ \\
\hline
\end{tabular}

Note. Principles from Day and Bamford (2002).

\section{Classroom Procedure}

The procedure outlined below represents a much more student-centered and differentiated approach than utilized in previous courses. Students carry out intensive reading and speed reading from more appropriately or individually leveled texts. In addition, due the creation of the intensive reading library, students are given more autonomy and choice in the genre of texts they read to access material more suited to their specific purposes or goals.

1. The teacher spends approximately twenty minutes at the beginning of each class explicitly teaching and giving students practice in a variety of reading skills and strategies.

2. Students complete one or two intensive reading passages and related activities from their textbooks.

3. Students compare answers with a partner before obtaining the answer key from the teacher to check their comprehension scores. At this stage, they can talk with partners and ask the teacher questions relating to any problems. 
4. Students choose an intensive reading passage from the library and repeat Steps 2-4 as many times as they can in the given time period. Students are encouraged to review incorrect answers outside of class.

5. Students enter the details of the texts (book title, level, passage number) and their comprehension scores onto their reading record sheet.

6. Students carry out a speed reading activity and record their time and comprehension scores on a chart.

7. In pairs, students summarize and discuss the intensive reading passages, speed reading passages, and the extensive reading done in and outside of class.

8. The teacher sets intensive reading, speed reading, and extensive reading for homework.

\section{Results}

The new system was used with the two groups of students in a 15-week course. At the end of the semester, both groups were given the same questionnaire (see appendix) to determine if their perceptions of the new reading course differed from that of their previous course.

Table 4

\section{Comparison of Post-Course Questionnaires}

\begin{tabular}{|l|c|c|}
\hline \multicolumn{1}{|c|}{$\begin{array}{c}\text { Question } \\
\text { Focus }\end{array}$} & \multicolumn{1}{c|}{$\begin{array}{c}\text { Results of questionnaire } \\
\text { on previous reading course }\end{array}$} & $\begin{array}{c}\text { Results of post-course questionnaire } \\
\text { on new reading course }\end{array}$ \\
\hline $\begin{array}{l}\text { Level of } \\
\text { enjoyment } \\
\text { (intrinsic } \\
\text { motivation) }\end{array}$ & $15 \%$ : enjoyable & $85 \%$ : enjoyable \\
\hline $\begin{array}{l}\text { Suitability to } \\
\text { study purposes } \\
\text { or goals } \\
\text { (extrinsic } \\
\text { motivation) }\end{array}$ & $\begin{array}{l}21 \% \text { : class or materials useful to } \\
\text { purposes or goals }\end{array}$ & $\begin{array}{l}70 \% \text { : class or materials useful to } \\
\text { purposes or goals }\end{array}$ \\
\hline Difficulty & $\begin{array}{l}28 \% \text { : level of the class is } \\
\text { appropriate }\end{array}$ & $88 \%$ : class level is appropriate \\
\hline
\end{tabular}

Table 4 shows that after the new reading course, students reported that they had generally enjoyed the class much more, found the materials more suitable for their individual purposes, and perceived the course level to be more appropriate to their own language level. However, limitations that should be noted are that all the results are based on students' self-reported survey questionnaire data; due to time constraints, more in-depth data collection methods such as interviews were not carried out.

\section{Conclusion}

By adopting a somewhat new approach to intensive reading, positive results were seen. The findings seem to support the vast body of literature suggesting that higher levels of learner autonomy and choice, along with appropriately leveled materials, can be a major factor in improving motivation (Carrell, Devine, \& Eskey, 1988; Childs, 2002; DelliCarpini, 2006; Harlen \& Malcolm, 1997; Šimanová, 2010; Tomlinson, 2003). By adopting a more student-centered and differentiated approach and applying some of the principles of extensive reading to intensive reading, problems of low intrinsic and extrinsic motivation and the challenge of 
dealing mixed abilities were successfully dealt with. Through the implementation of this approach, students' enjoyment levels went up, and learners were able to focus more on their individual areas of interest with regard to reading in English. The approach offers an alternative choice for teachers charged with teaching reading to medium or large groups of mixed ability learners.

\section{Author Note}

Darrell Wilkinson, World Language Center, Soka University, Tokyo, Japan.

Correspondence concerning this article should be addressed to Darrell Wilkinson, World Language Center, Soka University, 1-236 Tangi-cho, Hachioji, Tokyo 192-8577, Japan. E-mail: darrell@soka.ac.jp 


\section{References}

Bamford, J., \& Day, R. R. (1997). Extensive reading: What is it? Why bother? The Language Teacher, 21(12). Available at http://jaltpublications.org/old_ttt/files/97/may/extensive.html

Bell, T. (1998). Extensive reading: Why? And how? The Internet TESL Journal, 4(12). Available at http://iteslj.org/Articles/Bell-Reading.html

Bowler, B., \& Parminter, S. (2002). Mixed-level teaching: Tiered tasks and bias tasks. In J. C. Richards \& W. A. Renandya (Eds.), Methodology in language teaching; An anthology of current practice (pp. 59-63). Cambridge, England: Cambridge University Press.

Brown, H. D. (2007). Teaching by principles: An interactive approach to language pedagogy (pp. 357-389). Englewood Cliffs, NJ: Prentice Hall Regents.

Bruton, A. (2002). Extensive reading is reading extensively, surely? The Language Teacher, 26(11), 23-25.

Carrell, P. L., Devine, J., \& Eskey, D. E. (Eds.). (1988). Interactive approaches to second language reading. Cambridge, England: Cambridge University Press.

Childs, M. (2002, July 19). Sad fate of students who drop off the pace. The Daily Yomiuri, p. 14.

Day, R. R., \& Bamford, J. (2002). Top ten principles for teaching extensive reading. Reading in a Foreign Language, 14(2), 136-141.

Deci, E. L., \& Ryan, R. M. (1985). Intrinsic motivation and self-determination in human behavior. New York, NY: Plenum Press.

DelliCarpini, M. (2006). Scaffolding and differentiating instruction in mixed ability ESL Classes using a round robin activity. The Internet TESL Journal, 73 ).

Grabe, W. (1991). Current developments in second language reading research. TESOL Quarterly, 25(3), 375-406. http://dx.doi.org/10.2307/3586977

Harlen, W., \& Malcolm, H. (1997). Setting \& streaming: A research review. Edinburgh, Scotland: Scottish Council for Research in Education.

Hunt, A., \& Beglar, D. (2005). A framework for developing EFL reading vocabulary. Reading in a Foreign Language, 1 71 .

Krashen, S. D., \& Terrell, T. D. (1983). The natural approach: Language acquisition in the classroom. Hayward, CA: Alemany Press.

Laufer, B. (1989). What percentage of text-lexis is essential for reading comprehension? In C. Lauren \& M. Nordman (Eds.), Special language: From humans thinking to thinking machines (pp. 316-323). Clevedon, England: Multilingual Matters.

Macalister, J. (2008). Integrating extensive reading into an English for Academic Purposes program. The Reading Matrix, 8(1), 23-34. Available at http://www.readingmatrix.com/articles/macalister/article.pdf

Nation, I. S. P. (1983). Testing and teaching vocabulary. Guidelines, 5, 12-15.

Nation, I. S. P. (1990). Teaching and learning vocabulary. New York, NY: Newbury House.

Nation, I. S. P. (1997). The language learning benefits of extensive reading. The Language Teacher, 21(5), 13-16.

Nation, I. S. P. (2001). Learning vocabulary in another language. Cambridge, England: Cambridge University Press.

Nation, I. S. P. (2009). Teaching ESL/EFL reading and writing. New York, NY and Oxon, England: Routledge.

Prodromou, L. (1989). The mixed-ability class and the bad language learner. English Teaching Forum, 274), 2-8. 
Renandya, W. A., \& Jacobs, G. M. (2002). Extensive reading: Why aren't we all doing it? In J. C. Richards \& W. A. Renandya (Eds.), Methodology in language teaching: An anthology of current practice (pp. 295-302). Cambridge, England: Cambridge University Press.

Sehlaoui, A. S. (2001). Facing the challenge of teaching and learning EFL reading: Beyond the language of critique. Reading in a Foreign Language, 13(2), 615-629.

Šimanová, A. (2010) Dealing with mixed ability classes (Master's thesis). Retrieved from http://is.muni.cz/th/104237/pedf_m/?lang=en;id=183114

Tomlinson, C. A. (2003). Differentiating instruction for academic diversity. In J. M. Cooper (Ed.), Classroom teaching skills (7th ed., pp. 149-180). Boston, MA: Houghton Mifflin.

Waring, R. (1997). Graded and extensive reading -- Questions and answers. The Language Teacher, 21(5), 9-12.

Wilkinson, D. (2012). Student-centered activities in mixed-level classes. In A. Stewart \& N. Sonda (Eds.), JALT2011 Conference Proceedings (pp. 625-635). Available at http://jaltpublications.org/files/pdf-article/jalt2011-061.pdf 


\section{Appendix \\ Pre- and Post-Course Questionnaire}

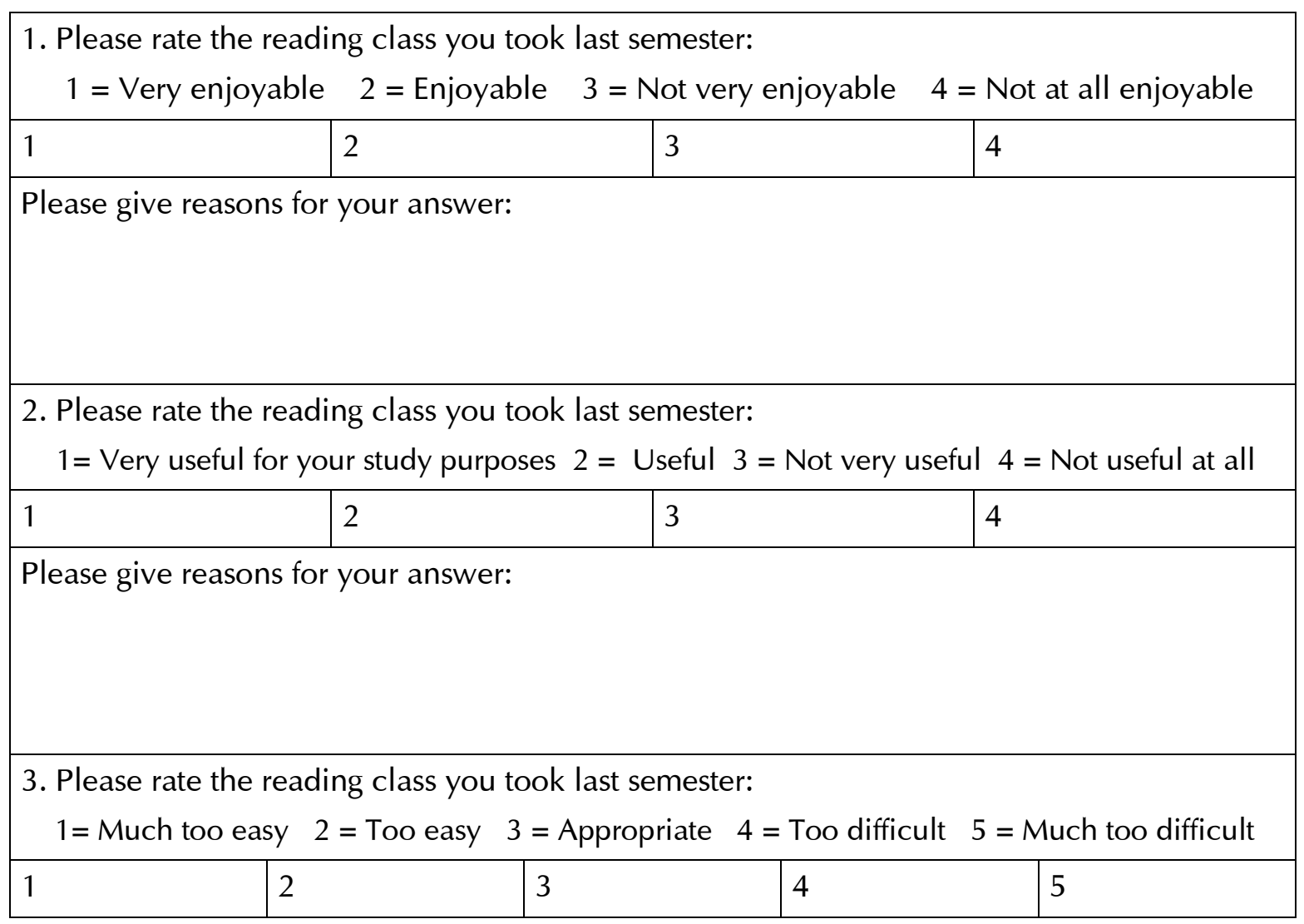

